\title{
Union Formation Among Men in the U.S.: Does Having Prior Children Matter?
}

Our study investigates whether fatherhood, and specifically involvement with nonresident children, influence men's entrance into marital and cohabiting unions. Using the National Survey of Families and Households, our findings suggest that neither resident nor nonresident children affect men's chances of entering a new marriage, but nonresident children have a positive effect on cohabitation. The positive association between nonresident children and men's union formation is not uniform; instead, we find that it is involvement with nonresident children, specifically visitation, that enhances men's chances of forming new unions. Whereas women's obligations to children from prior unions represent a resource drain that lowers their chances of union formation, our analysis suggests that involved nonresident fathers are more likely to enter subsequent unions than other men.

Department of Sociology and Anthropology, University of Richmond, Richmond, Virginia 23173 (sstewart@ richmond.edu).

\footnotetext{
*Department of Sociology, Bowling Green State University, Bowling Green, Ohio 43403.

**Department of Sociology and Population Studies Center, University of Michigan, Ann Arbor, Michigan 48106.
}

Key Words: child support, cohabitation, fatherhood, remarriage, visitation.
Whereas it is well known children from prior relationships lower women's chances of marriage and remarriage (Becker, Landes, \& Michael, 1977; Bumpass, Sweet, \& Martin, 1990; Clarkberg, Stolzenberg, \& Waite, 1995; Peters, 1986; Smock, 1990), the effect of prior children on men's union formation is less clear. In part, this gap in knowledge about men exists because children are far more likely to reside with their mothers than their fathers should a union end, and the role of residential parent entails considerable breadwinning and day-to-day caretaking responsibilities. For instance, it is argued that these responsibilities may reduce the time available to search for a spouse and deter potential spouses who recognize that they will be taking on stepchildren should marriage occur (Becker et al.; Lampard \& Peggs, 1999).

However, the focus on mothers in past research ignores the possibility that fathers' parenting responsibilities may impact their chances of forming new unions; the number of single, custodial fathers (including both never-married and divorced) is growing, and many nonresident fathers play substantial roles in their children's lives. Drawing on data from the National Survey of Families and Households, our study investigates two questions. First, we examine whether fatherhood (the existence of resident and/or nonresident children) is associated with men's likelihood of entering either 
cohabiting or marital unions. Second, because the majority of single fathers live apart from their children, we evaluate a potential mechanism for the effect of nonresident children by testing whether it is explained by men's involvement, here defined as economic support and visitation. We extend knowledge on the effect of prior children on men's union formation by incorporating cohabitation and involvement with nonresident children, two essential features of single fathers' lives.

Investigating the relationship between prior children and men's union formation is vital because high levels of divorce and growth in nonmarital childbearing mean that increasing proportions of men in the United States live apart from at least some of their biological children. Most broadly, these demographics suggest the importance of documenting complex parenting situations and their impact on union formation: Half of all marriages today are remarriages, and women and men with nonresident stepchildren-a spouse or partner's children who live elsewherecurrently account for over one half of all stepparents (Stewart, 2001). Additionally, if we wish to understand the process of union formation among men, a topic generating much attention given the retreat from marriage over the past few decades, then we need to evaluate the possible effect of resident and nonresident children.

\section{BACKGROUND ANd SignifICANCE}

Men have a higher rate of remarriage than women and remarry more rapidly (Glick, 1984), and this difference appears to be explained in part by women's obligations to children. Past research overwhelmingly shows that women who have children with previous partners have lower odds of first marriage, remarriage, and cohabitation (Becker et al., 1977; Bumpass et al., 1990; Clarkberg et al., 1995; Peters, 1986). This is especially true for women with large numbers of children or with young children (Buckle, Gallup, \& Rodd, 1996; Le Bourdais, Desrosiers, \& Laplante, 1995; Sweeney, 1997a; but see Beller \& Graham, 1985, and Koo \& Suchindran, 1980).

Theoretical explanations for mothers' lower chances of union formation have emphasized a variety of economic and socioemotional factors. One perspective is that daily caring for children impinges upon both the time and energy to seek a spouse (Becker et al., 1977; Lampard \& Peggs, 1999). Another is that child support and welfare income reduce the economic need to marry and allow women more time to search for an acceptable spouse (Beller \& Graham, 1985; Bennett, Bloom, \& Miller, 1995; Folk, Fox, Graham, \& Beller, 1992; Hutchens, 1979; Oppenheimer, 1988; Yun, 1992). Other scholars have emphasized the perspective of potential partners, suggesting that men may not be interested in investing in children with whom they share no biological ties (Trivers, 1974); may be hesitant to attempt to negotiate the ambiguous and difficult stepfather role (Marsiglio, 1992); or are unwilling to assume the financial costs associated with parenting another man's child (Lampard \& Peggs, 1999).

There are far fewer studies that analyze the effect of fatherhood on men's union prospects, and no study accounts for both the formation of cohabiting unions and involvement with nonresident children. Moreover, this research has yielded mixed findings. Whereas several studies provide evidence that prior children do not influence whether men remarry (Becker et al., 1977; Buckle et al., 1996; Glick, 1980; Lampard \& Peggs, 1999; Wolf \& MacDonald, 1979), a small number of studies have found that previous children negatively affect men's chances of forming a new union (Bernhardt \& Goldscheider, 1998; Clarkberg, 1999; Clarkberg et al., 1995; Sweeney, 1997a, 1997b). There are some additional limitations to this research. First, some of these studies are quite dated or use data from older cohorts (e.g., Becker et al.; Clarkberg; Clarkberg et al.; Sweeney, 1997a, 1997b; Wolf \& MacDonald). Second, the residence of men's prior children is often ambiguous (Clarkberg; Clarkberg et al.; Sweeney, 1997a), and children are assumed to be living elsewhere. This assumption is becoming less valid as more men live with their children after a union dissolves. The number of father-only families (single men with resident children) increased by $42 \%$ in the 1980 s, compared with a growth rate of $15 \%$ for mother-only families, even after eliminating single fathers who are living with a female partner (Garasky \& Meyer, 1996). Third, past research has been variable in terms of the types of men included in analyses. For example, the majority of research has been limited to divorced (Becker et al.; Sweeney, 1997a, 1997b; Wolf \& MacDonald) or never-married men (Nock, 1998b). A fourth limitation is that only a few studies incorporate nonmarital cohabitation in the definition of union formation. Given the sharp rise in cohabitation, it is important not to limit analysis 
of union formation to legal marriage. The majority of marriages (over one half) and the vast majority of remarriages (over two thirds) now begin as cohabitations, cohabitation is extremely common after union dissolution, and approximately one half of stepfamilies are now formed through cohabitation, rather than marriage (Bumpass \& Raley, 1995; Bumpass, Raley, \& Sweet, 1995; Smock, 2000). Studies of fathers' union formation that include cohabitation are problematic (Bernhardt \& Goldscheider, 1998; Clarkberg; Clarkberg et al.; Nock). One of them focuses on young, never-married men (Nock), providing a narrow view of nonresident fatherhood. Two studies rely upon men who graduated from high school in 1972 (Clarkberg; Clarkberg et al.) who were forming families in the late 1970s, quite some time before most marriages were preceded by cohabitation. A fourth study provides only cross-sectional analysis of the relationship between men's parental and union status (Bernhardt \& Goldscheider).

Previous research has identified a number of sociodemographic factors associated with men's union formation and parental involvement. Age is the most important determinant of whether a person remarries. Age at separation or divorce is negatively related to the remarriage of men (Becker et al., 1977; Haskey, 1987; Sweeney, 1997a), although the effect may be weaker for men than women (Lampard \& Peggs, 1999; Spanier \& Glick, 1980; Wilson \& Clarke, 1992). In addition, visitation with absent children is lower among older nonresident fathers (Veum, 1993), although older fathers may have more resources to pay child support (Zill, 1996). Another key variable is race. African Americans tend to have lower rates of marriage, remarriage, and cohabitation than Whites (Clarkberg et al., 1995; Smock, 1990; Sweeney, 1997b; Wilson \& Clarke). Non-White fathers may have higher levels of visitation with nonresident children than White fathers (Manning \& Smock, 1999; Seltzer, 1991), but may be less likely to pay child support (Sorensen, 1997). We also expect men's union history to influence the relationship between absent children and new union formation. Men who have been in a married or cohabiting union (including widowers) may be more likely to have a nonresident child and to form subsequent unions. Past research finds either no effect of education on marriage and cohabitation of men (Becker et al., 1977; Sweeney, 1997a, 1997b), or a positive relationship (Bloom et al., 1998; Clarkberg, 1999; Clarkberg et al.). Fathers' education is positively related to visitation and the payment of child support (Braver, Fitzpatrick, \& Bay, 1991; Maccoby \& Mnookin, 1992; Veum, 1993). Previous research clearly suggests that earnings are associated with higher probabilities of marriage and cohabitation for men (Becker et al.; Clarkberg; Clarkberg et al.; Glick; Glick \& Lin, 1987; Oppenheimer \& Lew, 1995). Nonresident fathers' earnings are positively associated with frequency of visits and child support payments (Hill, 1992; Maccoby \& Mnookin; Teachman, 1991). Religiosity is positively related to union formation among men (Clarkberg et al.), and several studies show lower levels of remarriage among Catholics than other religious affiliations (Chiswick \& Lehrer, 1990; Koo, Suchindran, \& Griffith 1984; Sweeney, 1997a, 1997b; Teachman \& Heckert, 1985; Wolf \& MacDonald, 1979). Several studies also find regional differences in remarriage (Bumpass et al., 1990; Chiswick \& Lehrer; Teachman \& Heckert).

\section{HYPOTHESES}

Why might we expect fatherhood to matter for men's union prospects? Although, unlike women, men are usually not living with children from prior unions, their economic and emotional investments in them may still be consequential. Moreover, these investments may influence the union formation of men differently than that of women.

Some evidence suggests that fatherhood hinders single men's chances of entering new unions, and this may be because of men's financial constraints or women's reluctance to form unions with men who have children. Similar to their effect on women, one hypothesis is that prior children are a resource drain, and that resident and involved nonresident fathers are less likely to enter unions than are childless men or uninvolved fathers. Involved nonresident fathers' emotional, social, and economic lives may center on children from prior unions, resulting in less time, ability, and inclination to search for a new partner. Lampard and Peggs's (1999) qualitative interviews with divorced fathers, for example, suggest that the complexities of visitation schedules can make it quite difficult to accommodate a new partner. Some of the fathers also reported wanting to avoid involving their children in relationships with women that may not last. Generally, balancing nonresident fatherhood and other roles simultaneously is a challenge (Marsiglio, 1992; Minton \& Pasley, 1996). Similarly, women may find involved nonresident fathers less desirable as spous- 
es or cohabiting partners. Women may view men who fulfill economic or social obligations to prior children as less attractive partners in the long run, even taking account of current earnings, given the continuing importance of men's income in union formation and the male breadwinner role in our culture (Nock 1998a; Oppenheimer \& Lew, 1995; Smock \& Manning, 1997; Sweeney, 1997c). Also, women with children may prefer substitute fathers who can devote all their energies toward a new family, rather than those with complicated ties.

Among fathers with resident children, the demands of fatherhood and concerns about the introduction of new partners would be even greater than for involved nonresident fathers. Women may be especially hesitant to form unions with custodial fathers given the stress and stigma associated with stepmotherhood (Santrock \& Sitterle, 1987; Smith, 1990). Therefore, we would expect resident fathers to have even lower odds of union formation than involved nonresident fathers. Finally, it is possible that women may view men who are fathers but not involved with their children as poor relationship and parenting material, leading to the expectation that uninvolved nonresident fathers will be less likely than either childless, resident, or involved nonresident fathers to enter a union.

A second hypothesis is that resident and nonresident fathers are more likely to form unions than childless men, such that fatherhood has a positive effect on union formation. First, there may be self-selectivity involved. Men who are fathers may simply be family-oriented and more motivated to form new committed relationships than childless men, all else equal. A minor variation is that involvement, rather than fatherhood itself, may account for this association because involvement may better capture a family orientation. Involved fathers may be more attractive to potential partners as well. Although some scholars consider children from previous unions a form of marital-specific capital that lowers chances of forming new unions (Becker et al., 1977), it is possible that good parenting represents transferable capital for men (Chiswick \& Lehrer, 1990), signaling high quality relationship and fathering skills to potential partners. Some indirect evidence supports this notion; having good parenting abilities is listed as the number one criterion in choosing a mate among remarried people with children (Dahl, Cowgill, \& Asmundssun, 1987). Fathers whose children reside with them as opposed to in another household would, all else being equal, demonstrate the highest level of involvement and would, on the basis of this hypothesis, have higher odds of union formation than would involved nonresident fathers.

A third hypothesis is that fatherhood and involvement with nonresident children have no effect on union formation. This could either be because some of the above explanations offset each other or because individuals make parenting and union choice decisions separately. Qualitative research suggests that many couples do not discuss the possible effect of children from previous unions on families before marrying (Bernstein, 1989; Ganong \& Coleman, 1989; Smith, 1990). Among nonresident fathers, child support and visitation may simply not be substantial or visible enough to impede or promote men's entry into new unions (Furstenberg \& Harris, 1992). More broadly, demographic research has shown that parenting and union formation have become increasingly decoupled (Pagnini \& Rindfuss, 1993; Raley, 2001).

Men's fatherhood status may have differential effects depending on the type of union formed: marriage versus cohabitation. Past research suggests that factors affecting entry into each union type vary in strength and direction of their influence (Axinn \& Thornton, 1993; Clarkberg, 1999; Clarkberg et al., 1995; Thornton, 1991; Thornton, Axinn, \& Hill, 1992; Thornton, Axinn, \& Teachman, 1995). These findings are not surprising because conceptually cohabitation and marriage differ. Cohabitation is associated with somewhat lower levels of commitment, paternal investment, durability, and institutionalization than marriage (Cooksey \& Craig, 1998; Manning, in press; Nock, 1995; Smock \& Manning, 2001). Most important, however, cohabitation is very common after first marriage and before remarriage. Thus many new unions among men who report having already had children (the majority of whom have had them in marriage) will begin as cohabiting unions, some eventually culminating in remarriage.

This research suggests further elaboration of our hypotheses. Prior research on the influence of children on cohabitation and marriage shows that premarital children decrease women's likelihood of marriage but increase the likelihood of cohabitation (Bennett et al., 1995). Among never-married men, prior children appear to increase rates of cohabitation but decrease rates of marriage compared with their childless counterparts (Nock, 1998b; see also Clarkberg, 1999; Clarkberg et al., 
1995). Marriage to a new partner, and the potential for new children, may involve a level of commitment not possible or desirable for resident and nonresident fathers. The lesser emotional and financial demands of cohabitation are compatible with fathers' prior family obligations, yet cohabitation allows men to live in the family environment that they desire and to which they may have become accustomed. Likewise, women unwilling to take on the demands of marriage to men with prior children may be willing to cohabit. Thus we expect that resident and nonresident children may deter men's entry into marriage and increase the probability of cohabitation. We assess these hypotheses net of sociodemographic factors associated with men's union formation and involvement with nonresident children.

\section{CURRENT INVESTIGATION}

This study employs event history models to examine the effect of fatherhood and involvement with nonresident children on men's likelihood of forming a marital or cohabiting union. We draw on nationally representative, longitudinal data from a diverse group of men and include those of all relationship backgrounds (never-married, divorced/separated/widowed, and those with and without prior cohabitation experience). Both economic (child support) and social (visitation) measures of involvement are used, arguably the two most important indicators of involved nonresident parenting. Although one past study (Bloom, Conrad, \& Miller, 1998) examined the effects of child support payments among divorced fathers on remarriage, the effects of visitation on entrance into marriage or cohabitation have not been examined.

Our first research question is straightforward: Net of background and socioeconomic factors, does fatherhood significantly affect men's entrance into marital and cohabiting unions? We build on prior research and examine the separate effects of resident and nonresident children and include cohabiting unions in the analysis. Our second research question focuses on whether and how nonresident fathers' involvement is associated with union formation. We evaluate the effect of child support and/or visitation with nonresident children on whether men enter new coresidential relationships.

\section{METHOD}

\section{Data}

Analyses were conducted using data from two waves of the National Survey of Families and Households (NSFH), a national probability sample of approximately 13,000 respondents randomly selected from each household, with a response rate of $74 \%$ (Sweet, Bumpass, \& Call, 1988). The primary advantage of the NSFH over other data sources is that it asks male respondents directly about their previous fertility experiences. Other national data sets neglect the fertility of men (e.g., National Survey of Family Growth, Current Population Survey), failing to provide even indirect (i.e., wives' reports) information on men's children prior to the current union. Another advantage of the NSFH is that it asks men directly where their previous children reside. Other data sources require the indirect identification of nonresident fathers that may misclassify children from previous unions who currently reside with their fathers as nonresident (e.g., Survey of Income and Program Participation). However, a limitation plaguing all studies relying on male respondents' reports is that men tend to be underrepresented in large social surveys and frequently fail to report nonresident children (Rendall, Clarke, Peters, Ranjit, \& Verropoulou, 1999).

The NSFH provides longitudinal data that allow for the prediction of union formation based on previous patterns of involvement with nonresident children. The first wave of the survey (NSFH1), conducted between 1987 and 1988, provides retrospective fertility and union histories from the perspective of men, information on the sociodemographic characteristics of men and their children, and fathers' own assessments of child support payments and visitation with children from previous unions. The second wave (NSFH2), conducted between 1992 and 1994, provides the dates of respondents' subsequent marriages and cohabitations. Respondents must have completed both waves of the survey to be included in the sample. About $71 \%$ of single fathers at NSFH1 completed NSFH2. We conducted analyses indicating that men with nonresident children have $30 \%$ lower odds of being reinterviewed at NSFH2 compared with childless men.

\section{Analytic Sample}

Our sample is comprised of a group of single men who were never-married, divorced, or widowed, 
and none of these men were currently cohabiting at NSFH1. These men may or may not have had children from a previous union. Our analytic sample was drawn from 1,248 male respondents not in a union at NSFH1 who completed the Wave 2 interview. Cases missing data on key variables were omitted, resulting in a sample of 1,226 single men. We conducted additional analyses on a subsample of 169 single men who reported nonresident children at NSFH1. Restricting some of our analyses to nonresident fathers enables us to determine how the level of involvement (visitation and child support) influences union formation, allowing a more refined understanding of fathers' investments. However, because of the small size of this sample, only tentative conclusions will be drawn from the supplemental analysis.

\section{Analytic Methods}

We employ multinomial models to estimate the odds that single men marry, single men cohabit, and men who enter unions marry, rather than cohabit. This strategy best reflects individuals' actual decision-making process. Other work on union choice presumes that cohabitation and marriage are alternatives; that is, individuals decide to form a union and then decide which type of union to form (e.g., Axinn \& Thornton, 1993; Clarkberg, 1999; Thornton et al., 1995). Yet qualitative research evidence suggests that young adults are deciding either to cohabit or to live in some other arrangement, but that marriage is not perceived as an option and does not enter the calculus (Sassler $\&$ Jobe, 2002). Thus our models are based on realistic conceptualizations of union choice that incorporate the possibility that men view cohabitation as a marriage alternative and as an alternative to being single.

Cox proportional hazards models (Cox, 1972) are used to estimate the effects of resident and nonresident children, and involvement with nonresident children (child support payments and visitation), on the formation of married and cohabiting unions. Using the PHREG procedure in SAS, we ran multinomial models for competing risks to simultaneously estimate each union type (married vs. single, cohabiting vs. single, married vs. cohabiting; Allison, 1995).

\section{Dependent Variable}

Union formation. We measure single men's risk of union formation between NSFH1 and NSFH2. At
NSFH2, respondents report the month and year they entered any marriages or cohabiting unions since NSFH1, as well as the date at which the union dissolved (if not in that union at NSFH2). Survival time is calculated in months from the date of the first interview to the date of the first married or cohabiting union. Although we include a control for the duration of pre-NSFH1 exposure to union formation (described below), this periodbased approach assumes the hazard of union formation is similar for men who have been single for different periods of time.

Of the 1,226 single men in the analytic sample, 594 men $(48 \%)$ formed a union between waves: 200 married and 394 formed a cohabiting union. Of the 169 nonresident fathers in the sample, 101 (60\%) formed a union, with 15 marrying and 86 cohabiting. Respondents who did not form a union between waves are censored at the NSFH2 interview date. The NSFH does not permit us to determine whether men formed a union with a previous or new partner, and a small number of nonresident fathers in our sample may have formed a union with their child's or children's biological mother. About a third (34\%) of the nonresident fathers in our sample have prior children born within marriage, and the formation of unions with previous spouses is extremely rare. In fact, no official statistics are available on the subject (R. Kreider, personal communication, July 31, 2002). However, research suggests that men whose children were born outside of marriage sometimes marry the child's mother later on (Waller \& McLanahan, 2001). Assuming that the birth of a child would encourage such unions, a positive effect of prior children on union formation may partially reflect romantic ties to previous partners.

\section{Independent Variables}

Fatherhood status. At NSFH1, respondents were asked to list any biological or adopted children age 0 to 18 residing with them and/or elsewhere (ties to prior stepchildren are not considered). On the basis of this information, we constructed a dichotomous variable indicating whether the respondent has no children versus any children, irrespective of residence. Then we constructed a trichotomous variable indicating whether men have no children, only resident children, or any nonresident children. We consider only minor children (under age 18), and nonresident children may or may not live with their biological mother (less than $10 \%$ do not live with their mothers). A 
few $(n=12)$ of the nonresident fathers also have biological children residing with them. Categorizing these men as having resident as opposed to nonresident children does not alter our findings. We did not include in our fatherhood measure a small number of men who had a child between NSFH1 and the formation of a married or cohabiting union because data on children's residence and fathers' level of involvement between waves were not collected $(n=25)$. Our analyses may therefore understate the extent of fatherhood among single men and the effect of father involvement on union formation.

Involvement with nonresident children. Involvement with nonresident children is assessed at NSFH1 in terms of child support payments to and visitation with a focal nonresident child randomly selected at the time of the survey. Men with any nonresident children are divided into two groups: those who make no payments or visits and those who make any payment or visits. We retain the fatherhood categories containing no children and only resident children for comparison. This measurement strategy allows us to test whether it is actual investments in nonresident children (measured broadly as any payments or visits), or simply the existence of nonresident children that is associated with union formation. We consider fathers to have made payments if they reported that they paid at least something toward the support of their child in the last 12 months. We consider fathers to have visited their child if they reported seeing their child in-person at least once in the last year. For analyses limited to the smaller sample of nonresident fathers, we measure involvement separately in terms of the amount of monthly child support paid and the frequency of in-person visits (none, yearly, monthly). Variance inflation factors (VIFs) indicate multicollinearlity between social and financial contact will not affect our findings (McClendon, 1994).

\section{Control Variables}

Sociodemographic factors associated with men's union formation and involvement with nonresident children are included in all multivariate analyses as controls. Men's age in years is assessed at NSFH1. We use men's age at NSFH1, rather than men's age at separation or divorce (e.g., Becker et al., 1977; Haskey, 1987; Sweeney, 1997a) because exposure to union formation is assessed since NSFH1. However, measuring men's age at separation or divorce as opposed to NSFH1 does not alter our findings. Race is measured dichotomously as White and Non-White. There were too few cases to distinguish Hispanic origin, and Hispanics are included in the Non-White category. Men are coded into four categories based on their previous union status: no previous unions, evercohabited/never-married, ever-married/never-cohabited, and ever-cohabited/ever-married.

We acknowledge that analyses based on a sample of single men at NSFH1 is left truncated and may omit substantial numbers of men who formed unions before the first wave of the survey. Our sample may therefore be biased toward men with a lower likelihood of union formation. To partially address this issue, we include a control for the interval between men's exposure to union formation and the NSFH1 interview. For men who have been in a previous union, we use the date of separation from (date last lived with) their most recent partner as the beginning of the interval. For men who have not been in a union prior to NSFH1, we measure this interval from the date of the respondent's 18th birthday, the point at which most men are in the position to set up their own household. This approach has the advantage of partially accounting for men's declining risk of union formation over time (Wilson \& Clarke, 1992). However, whether this variable is included in the model does not alter our substantive findings.

Level of education at NSFH1 is coded as four dummy variables: less than high school, high school, some college, and college degree or above. Respondents' total yearly earnings are calculated as the sum of their wages, salary, and selfemployment income at NSFH1. We take the natural log of total earnings to reduce the effect of outliers. Men missing earnings information (less than $10 \%$ ) were coded to the mean. Fathers' religious attendance at NSFH1 is measured with four dummy variables: never attend, yearly attendance, monthly attendance, and weekly attendance. We initially included controls for Catholic background and region of residence. The inclusion of these variables did not contribute to model fit and they were subsequently dropped.

For our analysis of nonresident fathers, we include some additional controls: the focal nonresident child's sex and age, the child's distance (in miles) from the father, and the number of full siblings in the child's household. The multivariate analysis includes a squared term for distance in order to detect a potential nonlinear effect of dis- 
Table 1. Distributions (\%) of Independent Variables for Samples of Single Men and NonResident Fathers

\begin{tabular}{|c|c|c|}
\hline Characteristics & $\begin{array}{l}\text { All Single Men } \\
\quad(N=1,226)\end{array}$ & $\begin{array}{c}\text { Nonresident Fathers } \\
\quad(n=169)\end{array}$ \\
\hline \multicolumn{3}{|l|}{ Fatherhood status } \\
\hline No children & 88.2 & \\
\hline Only resident children & 2.7 & \\
\hline Any nonresident children & 9.1 & \\
\hline \multicolumn{3}{|l|}{ Involvement with nonresident children } \\
\hline No payments or visits & 1.1 & \\
\hline Any payments or visits & 8.0 & \\
\hline Monthly child support paid in dollars $(M)$ & & 180.5 \\
\hline \multicolumn{3}{|l|}{ Visits with child in last year } \\
\hline None & & 17.9 \\
\hline Yearly & & 17.1 \\
\hline Monthly or more & & 65.0 \\
\hline \multicolumn{3}{|l|}{ Characteristics of men } \\
\hline Age at NSFH1 $(M)$ & 32.0 & 35.3 \\
\hline \multicolumn{3}{|l|}{ Race } \\
\hline White & 78.5 & 62.4 \\
\hline Non-White & 21.5 & 37.6 \\
\hline \multicolumn{3}{|l|}{ Union history } \\
\hline No previous unions & 62.0 & 10.1 \\
\hline Ever-cohabited/never-married & 11.5 & 15.6 \\
\hline Ever-married/never-cohabited & 16.7 & 41.5 \\
\hline Ever-married/ever-cohabited & 9.8 & 32.8 \\
\hline Months from previous union to NSFH1 interview $(M)$ & 89.3 & 61.1 \\
\hline \multicolumn{3}{|l|}{ Education } \\
\hline Less than high school & 15.4 & 24.6 \\
\hline High school & 35.9 & 30.7 \\
\hline Some college & 30.8 & 25.7 \\
\hline College degree or more & 17.9 & 19.0 \\
\hline Earnings in last year in dollars $(M)$ & $13,565.0$ & $21,769.0$ \\
\hline \multicolumn{3}{|l|}{ Church attendance } \\
\hline Never & 30.9 & 32.1 \\
\hline Yearly & 32.5 & 39.3 \\
\hline Monthly & 14.5 & 13.4 \\
\hline Weekly & 22.0 & 15.1 \\
\hline \multicolumn{3}{|l|}{ Characteristics of focal nonresident child } \\
\hline \multicolumn{3}{|l|}{ Sex } \\
\hline Female & & 53.7 \\
\hline Male & & 46.3 \\
\hline Age $(M)$ & & 8.6 \\
\hline Distance in miles from father $(M)$ & & 336.5 \\
\hline Number of full siblings $(M)$ & & 0.5 \\
\hline \multicolumn{3}{|l|}{ Legal agreement about child support and/or visitation } \\
\hline Yes & 57.7 & \\
\hline No & 42.3 & \\
\hline
\end{tabular}

Note: Weighted percentages and unweighted Ns.

tance on men's union formation (e.g., Manning \& Smock, 1999). We also control for the existence of a legal agreement pertaining to visitation and/ or child support. The literature on nonresident father involvement suggests that these factors may influence the relationship between involvement and men's union formation.

Table 1 presents the frequency distributions of the independent variables included in our analysis of union formation for all single men and nonresident fathers.

\section{Analysis Strategy}

We estimate a series of models to test our hypotheses. First, we evaluate the effect of fatherhood on men's union formation and test empirically whether it is important to distinguish 
Table 2. Risk of Cohabitation and Marriage by Parental Status of Single Men

\begin{tabular}{|c|c|c|c|}
\hline Characteristic & $\begin{array}{l}\text { Married Union } \\
\text { Versus } \\
\text { Stayed Single }\end{array}$ & $\begin{array}{c}\text { Cohabiting Union } \\
\text { Versus } \\
\text { Stayed Single }\end{array}$ & $\begin{array}{c}\text { Married Union } \\
\text { Versus } \\
\text { Cohabiting Union }\end{array}$ \\
\hline \multicolumn{4}{|l|}{ Fatherhood status } \\
\hline No children (omitted category) & - & - & - \\
\hline Only resident children & 1.508 & 1.061 & 1.575 \\
\hline Any nonresident children & 0.614 & $1.337 *$ & $0.425^{* *}$ \\
\hline \multicolumn{4}{|l|}{ Controls } \\
\hline Age at NSFH1 & $0.969 * * *$ & $0.945 * * *$ & $1.031 * *$ \\
\hline \multicolumn{4}{|l|}{ Race } \\
\hline White (omitted category) & - & - & - \\
\hline Non-White & $0.518 * * *$ & 0.898 & $0.552 * *$ \\
\hline \multicolumn{4}{|l|}{ Union history } \\
\hline No previous unions (omitted category) & - & - & - \\
\hline Ever-cohabited/never-married & 1.119 & $2.040 * * *$ & 0.802 \\
\hline Ever-married/never-cohabited & 1.222 & 1.500 & 0.705 \\
\hline Ever-married/ever-cohabited & 1.329 & $3.026 * * *$ & 0.633 \\
\hline Months to NSFH1 interview & $0.996^{* *}$ & 0.999 & $0.997 *$ \\
\hline \multicolumn{4}{|l|}{ Education } \\
\hline Less than high school & 0.919 & 1.001 & 0.872 \\
\hline High school (omitted category) & - & - & - \\
\hline Some college & 0.927 & 0.818 & 1.023 \\
\hline College degree or more & 1.140 & 0.862 & 1.019 \\
\hline Earnings in last year & $1.064^{*}$ & $1.036^{*}$ & 1.027 \\
\hline \multicolumn{4}{|l|}{ Church attendance } \\
\hline Never (omitted category) & - & - & - \\
\hline Yearly & 1.368 & 0.868 & 1.398 \\
\hline Monthly & $2.232 * * *$ & 1.210 & $2.320 * * *$ \\
\hline Weekly & $2.052 * * *$ & $0.648^{*}$ & $2.819 * * *$ \\
\hline Model $\chi^{2}$ & $134.403 * * *$ & $256.704 * * *$ & $64.598 * * *$ \\
\hline$d f$ & 15 & 15 & 15 \\
\hline$N$ & 1,226 & 1,226 & 1,226 \\
\hline
\end{tabular}

$* p<.05 .{ }^{* *} p<.01 . * * * p<.001$.

between resident and nonresident children. Second, we test whether the effect of nonresident fatherhood on union formation is explained by parental involvement (child support and visitation). Third, we examine separately how the amount of child support and visitation affect men's union formation in a sample of nonresident fathers.

\section{RESULTS}

Table 2 shows the effect of prior children on single men's transition to marriage, cohabitation, and, among men who formed a union, the likelihood of marriage versus cohabitation. The models control for sociodemographic variables is listed in Table 1. Results are expressed in relative risks, which are the exponentiated values of the regression coefficients $\left(e^{b}\right)$ and indicate the change in risk associated with a one-unit change in an in- dependent variable. Relative risks less than 1.00 indicate a reduced risk, whereas relative risks greater than 1.00 indicate an increased risk.

Our first goal was to determine whether men who are fathers have significantly different patterns of union formation than childless men. In results not shown, we found that men who have children (resident or nonresident) have 28\% higher odds of cohabitation as opposed to staying single compared with men with no children $(p=$ .08 ), but similar odds of marriage. These findings are consistent with research suggesting that children from previous unions do not influence whether men remarry (Becker et al., 1977; Buckle et al., 1996; Glick, 1980; Wolf \& MacDonald, 1979) but positively influence cohabitation (Nock, 1998b). Differentiating men's children by their residential status was found to significantly improve model fit, indicating that it is important to 
Table 3. Risk of Cohabitation and Marriage by Parental Involvement of Single Men ${ }^{a}$

\begin{tabular}{|c|c|c|c|}
\hline & $\begin{array}{l}\text { Married Union } \\
\text { Versus } \\
\text { Stayed Single }\end{array}$ & $\begin{array}{c}\text { Cohabiting Union } \\
\text { Versus } \\
\text { Stayed Single }\end{array}$ & $\begin{array}{c}\text { Married Union } \\
\text { Versus } \\
\text { Cohabiting Union }\end{array}$ \\
\hline \multicolumn{4}{|l|}{ Involvement with nonresident children } \\
\hline $\begin{array}{l}\text { No children (omitted category) } \\
\text { Only resident children } \\
\text { Any nonresident children }\end{array}$ & 1.517 & 1.066 & 1.582 \\
\hline $\begin{array}{l}\text { No payments or visits } \\
\text { Any payments or visits }\end{array}$ & $\begin{array}{l}0.264 \\
0.681\end{array}$ & $\begin{array}{l}0.791 \\
1.460 *\end{array}$ & $\begin{array}{l}0.231 \\
0.454^{*}\end{array}$ \\
\hline $\begin{array}{l}\text { Model } \chi^{2} \\
d f \\
N\end{array}$ & $\begin{array}{l}135.495 * * * \\
16 \\
1,226\end{array}$ & $\begin{array}{l}260.202 * * * \\
16 \\
1,226\end{array}$ & $\begin{array}{l}65.098^{* * * *} \\
16 \\
1,226\end{array}$ \\
\hline
\end{tabular}

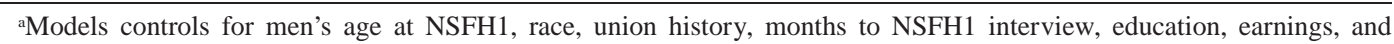
church attendance.

$* p<.05 . * * p<.01 . * * * p<.001$.

distinguish between resident and nonresident children to fully understand men's union formation patterns (results not shown). Thus Table 2 presents men's risk of cohabitation and marriage by the presence of resident and nonresident children. The first column of Table 2 indicates that neither resident nor nonresident children influence men's entry into marriage versus staying single. These results suggest that single men with previous children are no more or less likely to marry than childless men. Resident children have a significant positive effect on marriage in the zero-order model, but the effect is reduced to nonsignificance with the addition of background factors, suggesting that the effect may be spurious (results not shown). However, because this contrast group is based on a relatively small number of men and the magnitude of the effect is relatively large (a $50 \%$ increase), it is not safe to conclude that the risk of marriage versus cohabitation is not higher among men with resident children at the national level. On the other hand, nonresident children do not significantly reduce the likelihood of marriage in either the zero-order or control model.

The second column of Table 2 shows that having nonresident children increases single men's risk of forming a cohabiting union by $34 \%$. The effect of resident children is positive but not significant in both the multivariate and zero-order models (results not shown). The third column of Table 2 suggests that among men who formed a union, nonresident children influence the type of union formed. Men with nonresident children have a 58\% lower risk of marriage than cohabitation. In the zero-order model, resident children have a significant positive effect on men's risk of marriage that is rendered nonsignificant with the addition of controls. Because this effect is based on a small sample of men, it cannot be ruled out that men's resident children have a positive effect on marriage in the population.

Table 3 examines how involvement with nonresident children influences men's union formation. The effects of the control variables operate in a similar manner to those above and are not shown. The effect of resident children is also similar to previous models. The first column indicates that involvement with nonresident children does not affect men's transition to marriage from singlehood, although the lack of significant effects could be attributable to the relatively small number of nonresident fathers who marry. However, the second column shows that whereas single men with nonresident children who report no involvement have a similar risk of cohabitation as men with none, men with nonresident children who report some involvement have nearly a $50 \%$ greater risk of forming a cohabiting union as opposed to staying single. The difference between involved and uninvolved fathers is close to significance at $p=.08$. Among men who formed a union (column 3), men who have nonresident children and are involved with them have a significantly lower risk of marrying as opposed to cohabitating compared with childless men. The lack of significance of the effect of no involvement indicates that men with nonresident children who are not involved may have a similar risk of marriage as opposed to cohabiting. However, on the basis of the relatively large magnitude of the effect, it is possible that this finding is the result of the small size of the sample $(n=23)$, rather than a real indication of the effect of noninvolvement (the difference between involved and uninvolved fathers is not sta- 
Table 4. Men's Risk of Cohabitation and Marriage By ChILd Support PAYMENTS AND Visitation

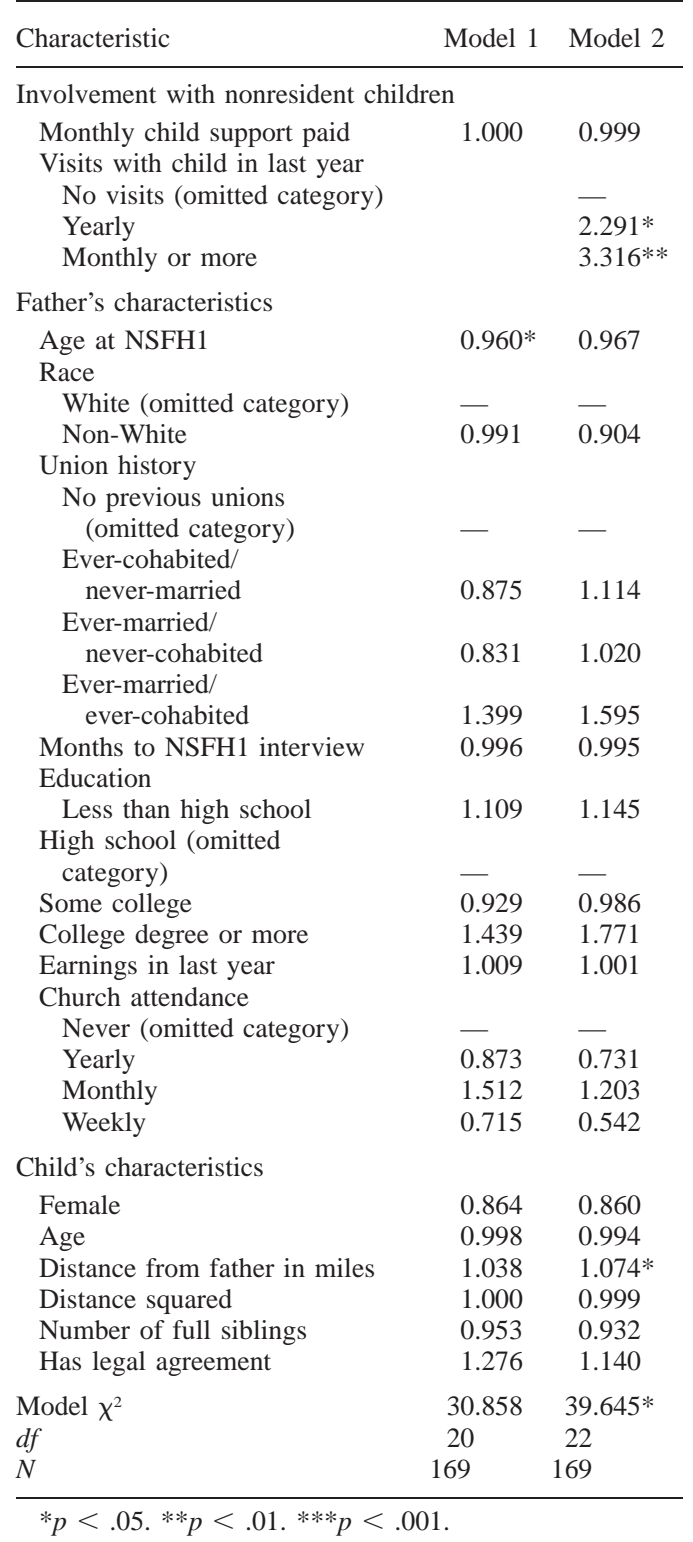

tistically significant). Nonetheless, these results indicate that it is involvement with nonresident children, rather than the existence of nonresident children, that underlies nonresident fathers' greater propensity to cohabit.

Table 4 presents results restricted to nonresident fathers. The number of nonresident fathers who married was too small for us to distinguish between union type (85\% of nonresident fathers formed cohabiting unions). Results primarily re- flect the effect of involvement on the formation of cohabiting unions, and models that limit union formation to cohabitation provided similar estimates. First, we include the amount of child support nonresident fathers paid in the last year on a monthly basis. In contrast to Bloom et al. (1998), the effect of child support on the union formation of nonresident fathers is not statistically significant in either the multivariate or zero-order models (results not shown). We also ran a similar set of models using any child support paid, rather than amount paid. Whether any payments were made had no effect on nonresident fathers' union formation.

We include fathers' level of visitation with nonresident children in the second model. Results suggest that nonresident fathers who visit their children yearly have over twice the risk of forming a union, and fathers who visit monthly have over three times the risk of forming a union, compared with fathers who did not visit their children in the previous year. However, the difference between yearly and monthly visits is not statistically significant. A model that includes an interaction term between payments and visitation indicates that the positive effect of visitation is not dependent on the amount of child support paid (results not shown). These results suggest that the positive effect of nonresident children is at least partially explained by visitation.

\section{DISCUSSION}

Remarriage and cohabitation among adults with children from previous relationships have become increasingly common modes of family formation. Whereas some prior research has examined the effect of men's new children on economic and social involvement with prior children, the effects of prior children on men's subsequent family formation has received little attention. The few studies that have examined this relationship are limited to a high school graduation cohort from 30 years ago (Clarkberg, 1999; Clarkberg et al., 1995) and young never-married fathers (Nock, 1998b), or ignore cohabitation (Sweeney, 1997a, 1997b). None of these studies provide information on potential mechanisms for the effect of prior children.

One of our most important findings is that having nonresident children increases men's likelihood of forming a cohabiting relationship. This is consistent with the fatherhood factor hypothesis. The hypothesis involves the idea that men who 
are actively engaged in parenting may be viewed as good fathers, enhancing their attractiveness to potential partners. The hypothesis also encompasses the possibility that men who are involved parents are themselves predisposed toward family life, leading them to pursue committed, new unions more quickly than other men.

To provide a more direct test of the fatherhood factor hypothesis, our analysis also investigated whether the effects of nonresident fatherhood operate through actual involvement with prior children, proxied by child support and visits. Our findings are consistent with the hypothesis-the effect of nonresident children is conditional on involvement, specifically visitation. Uninvolved nonresident fathers do not appear to have increased chances of union formation; it is only the involved fathers who do. However, due to the small number of uninvolved nonresident fathers in our sample $(n=23)$, future studies should reexamine this issue. Our estimates suggest that, even taking account of an array of sociodemographic variables, fathers who visit their nonresident children at least monthly have over three times the chance of forming a new union than fathers who do not visit their children.

The fact that involvement increases the likelihood of forming a cohabiting union, and not a formal marriage, is unsurprising given recent trends. Cohabitation, particularly among those with prior cohabitation or marriage experience, has become so common that people who marry directly are an increasingly select population (e.g., Smock, 2000). Of the nonresident fathers in our sample who entered any union between the survey waves, the vast majority of them entered cohabitations, but many of these men will likely go on to marry their partner. It seems that cohabitation is more compatible than marriage, at least initially, with involved nonresident fathers' social roles. Men who have nonresident children are already living outside of a traditional family model, suggesting that informal unions would perhaps be more acceptable to them than to childless men.

Our results also demonstrate the importance of distinguishing between resident and nonresident children. Single men with resident children, arguably the most involved fathers, have not been shown by our analysis to be more likely to form a union. This study suggests that single resident fathers' chances of marriage and cohabitation are similar to those of men without children. One explanation is that resident children are not a factor in men's decisions to form unions. However, this is unlikely in light of the evidence presented above with respect to nonresident children. Another is that being a primary caretaker to young children detracts from custodial fathers' predisposition toward union formation. A third is that whereas women are attracted to men who are good fathers to children in other households, union formation to men with resident children entails a commitment (stepmotherhood) that many women are not willing to make. Because our findings are based on the experiences of a small number of single, resident fathers $(n=77)$, our ability to achieve statistically significant results may have been hampered. Thus future research is needed on the union formation patterns of this growing population of men.

There are a few limitations to our study. First, men tend to underreport nonresident children in national surveys (Rendall et al., 1999) as well as overestimate child support payments and visitation (Seltzer \& Brandreth, 1994). Relatively few nonresident fathers in our study reported no payments or visitation in the last year, suggesting that our sample may be biased toward involved fathers. Second, our estimates may be affected by sample attrition. It is well known that it is more difficult to retain nonresident fathers in longitudinal surveys than other men or than women, and men who formed a union between waves may have been more likely to complete the second wave of the survey. At the same time, our findings would likely be stronger if the men in our sample were representative of nonresident fathers as a whole because we are not contrasting the effect of involvement against the least involved nonresident fathers, who were probably not interviewed. Third, we rely on reports of involvement at one point in time and assume involvement remains stable between waves. Yet involvement with nonresident children has been shown to fluctuate over time (Manning \& Smock, 1999). Future work should utilize longitudinal data in which father involvement is measured across the life of the child. Finally, we know little about the quality of the visitation between nonresident fathers and their children. It may be the quality of involvement that underlies the positive effect, rather than simply visitation frequency (Amato \& Gilbreth, 1999). This is an important area for future research.

Overall, this study improves our understanding of men's family lives and how these lives are being affected by recent demographic trends. Our results are consistent with a conceptualization of contemporary fatherhood that emphasizes se- 
quences. That is, men are moving sequentially from one union to another, often leaving behind biological children from prior unions, and acquiring new biological children or stepchildren-a pattern of family formation that has been termed conjugal succession (Furstenberg \& Spanier, 1984). Although the general concept of conjugal succession can apply to women as well, the key difference is that, overwhelmingly, women are continuing to live with all of their biological children. Given the literature showing that children decrease women's union prospects (e.g., Koo \& Suchindran, 1980; Koo et al., 1984), our finding that prior children enhance men's union formation adds to research (e.g., King, 1999), suggesting an important gender asymmetry in the meaning and consequences of parenting. Additionally, family policy that keeps men tied to children from prior unions through visitation and child support may have the unanticipated result of creating relatively unstable family environments, based on cohabitation, for men's new partners and children.

\section{Note}

This paper was presented at the 2001 meetings of the Population Association of America in Washington, DC, March 29-31. This research was supported by grants HD34391 and HD34392 from the National Institute of Child Health and Human Development.

\section{REFERENCES}

Allison, P. D. (1995). Survival analysis using the SAS system. Cary, NC: The SAS Institute.

Amato, P. R., \& Gilbreth, J. G. (1999). Nonresident fathers and children's well-being: A meta-analysis. Journal of Marriage and the Family, 61, 557-573.

Axinn, W. G., \& Thornton, A. (1993). Mothers, children, and cohabitation: The intergenerational effects of attitudes and behavior. American Sociological Review, 58, 233-246.

Becker, G. S., Landes, E. M., \& Michael, R. T. (1977). An economic analysis of marital instability. Journal of Political Economy, 85, 1141-87.

Beller, A. H., \& Graham, J. W. (1985). Variations in the economic well-being of divorced women and their children: The role of child support income. In M. David \& T. Smeeding (Eds.), Horizontal equity, uncertainty, and economic well-being (pp. 471-506). Chicago: The University of Chicago Press.

Bennett, N. G., Bloom, D. E., \& Miller, C. K. (1995). The influence of nonmarital childbearing on the formation of first marriages. Demography, 32, 47-62.

Bernhardt, E. M., \& Goldscheider, F. K. (1998). Who lives in a family? The determinants of union and parental status in Sweden and the United States. PSTC Working Paper No. 98-04, Population Studies and Training Center. Providence, RI: Brown University.

Bernstein, A. C. (1989). Yours, mine, and ours. New York: Norton.
Bloom, D. E., Conrad, C., \& Miller, C. (1998). Child support and fathers' remarriage and fertility. In I. Garfinkel, S. S. McLanahan, D. R. Meyer, \& J. A. Seltzer (Eds.), Fathers under fire (pp. 128-156). New York: Russel Sage Foundation.

Braver, S., Fitzpatrick, P., \& Bay, C. (1991). Noncustodial parents' reports of child support payments. Family Relations, 40, 180-185.

Buckle, L., Gallup, G. G., \& Rodd, Z. A. (1996). Marriage as a reproductive contract: Patterns of marriage, divorce, and remarriage. Ethology and Sociobiology, 17, 363-377.

Bumpass, L. L., \& Raley, R. K. (1995). Redefining single-parent families: Cohabitation and changing family reality. Demography, 32, 97-109.

Bumpass, L., Raley, R. K., \& Sweet, J. A. (1995). The changing character of stepfamilies: Implications of cohabitation and nonmarital childbearing. Demography, 32, 425-436.

Bumpass, L. L., Sweet, J., \& Martin, T. C. (1990). Changing patterns of remarriage. Journal of Marriage and the Family, 52, 747-756.

Chiswick, C. U., \& Lehrer, E. L. (1990). On marriagespecific human capital. Journal of Population Economics, 3, 193-213.

Clarkberg, M. (1999). The price of partnering: The role of economic well-being in young adults' first union experiences. Social Forces, 77, 945-968.

Clarkberg, M., Stolzenberg, R. M., \& Waite, L. J. (1995). Attitudes, values, and entrance into cohabitational versus marital unions. Social Forces, 74, 609-634.

Cooksey, E. C., \& Craig, P. H. (1998). Parenting from a distance: The effects of paternal characteristics on contact between nonresidential fathers and their children. Demography, 35, 187-200.

Cox, D. R. (1972). Regression models and life tables. Journal of the Royal Statistical Society, Series B, 34, 187-220.

Dahl, A. S., Cowgill, K. M., \& Asmundssun, R. (1987). Life in remarriage families. Social Work, 32, 40-44.

Folk, K., Fox, J., Graham, W., \& Beller, A. H. (1992). Child support and remarriage. Journal of Family Issues, 13, 142-157.

Furstenberg, F. F., \& Harris, K. M. (1992). The disappearing American father? Divorce and the waning significance of biological parenthood. In S. South \& S. E. Tolnay (Eds.), The changing American family (pp. 197-223). San Francisco: Westview Press.

Furstenberg, F. F., \& Spanier, G. B. (1984). Recycling the family: Remarriage after divorce. Beverly Hills, CA: Sage.

Ganong, L. H., \& Coleman, M. (1989). Preparing for remarriage: Anticipating the issues, seeking solutions. Family Relations, 38, 28-33.

Garasky, S., \& Meyer, D. R. (1996). Reconsidering the increase in father-only families. Demography, 33, 385-393.

Glick, P. C. (1980). Remarriage: Some recent changes and variations. Journal of Family Issues, 1, 455-478.

Glick, P. C. (1984). Marriage, divorce, and living arrangements. Journal of Family Issues, 5, 7-26.

Glick, P. C., \& Lin, S. L. (1987). Remarriage after divorce. Sociological Perspectives, 30, 162-79.

Haskey, J. (1987). Social class differentials in remar- 
riage after divorce: Results from a forward linkage study. Population Trends, 47, 34-42.

Hill, M. S. (1992). The role of economic resources and remarriage in financial assistance for children of divorce. Journal of Family Issues, 13, 158-178.

Hutchens, R. M. (1979). Welfare, remarriage, and marital search. American Economic Review, 69, 369-379.

King, R. B. (1999). Time spent in parenthood status among adults in the United States. Demography, 36, 377-385.

Koo, H. P., \& Suchindran, C. M. (1980). Effect of children on women's remarriage prospects. Journal of Family Issues, 1, 497-515.

Koo, H. P., Suchindran, C. M., \& Griffith, J. D. (1984). The effects of children on divorce and re-marriage: A multivariate analysis of life table probabilities. Population Studies, 38, 451-471.

Lampard, R., \& Peggs, K. (1999). Repartnering: The relevance of parenthood and gender to cohabitation and remarriage among the formerly married. British Journal of Sociology, 50, 443-465.

Le Bourdais, C., Desrosiers, H., \& Laplante, B. (1995). Factors related to union formation among single mothers in Canada. Journal of Marriage and the Family, 57, 410-420.

Maccoby, E. E., \& Mnookin, R. H. (1992). Dividing the child: Social and legal dilemmas of custody. Cambridge, MA: Harvard University Press.

Manning, W. D. (in press). The implications of cohabitation for children's well-being. In A. Booth \& A. C. Crouter (Eds.), Just living together: Implications for children, families, and public policy. Lawrence-Erlbaum.

Manning, W. D., \& Smock, P. J. (1999). New families and nonresident father-child visitation. Social Forces, 78, 87-116.

Marsiglio, W. (1992). Stepfathers with minor children living at home. Journal of Family Issues, 13, 195214.

McClendon, M. J. (1994). Multiple regression and causal analysis. Itasca, IL: Peacock.

Minton, C., \& Pasley, K. (1996). Fathers' parenting role identity and father involvement. Journal of Family Issues, 17, 26-45.

Nock, S. L. (1995). A comparison of marriages and cohabiting relationships. Journal of Family Issues, 16, 53-76.

Nock, S. L. (1998a). Marriage in men's lives. New York: Oxford University Press.

Nock, S. L. (1998b). The consequences of premarital fatherhood. American Sociological Review, 63, 250263.

Oppenheimer, V. K. (1988). A theory of marriage timing. American Journal of Sociology, 94, 563-591.

Oppenheimer, V. K., \& Lew, V. (1995). American marriage formation in the eighties: How important was women's economic independence? In K. O. Mason \& A. Jensen (Eds.), Gender and family change in industrialized countries (pp. 105-38). Oxford: Clarendon Press.

Pagnini, D. L., \& Rindfuss, R. R. (1993). The divorce of marriage and childbearing: Changing attitudes and behavior in the United States. Population and Development Review, 19, 331-347.

Peters, E. (1986). Factors affecting remarriage. In L. B.
Shaw (Ed.), Midlife women at work (pp. 99-114). Lexington, MA: Heath.

Raley, R. K. (2001). Increasing fertility in cohabiting unions: Evidence for the second demographic transition in the United States? Demography, 38, 59-66.

Rendall, M. S., Clarke, L., Peters, H. E., Ranjit, N., \& Verropoulou, G. (1999). Incomplete reporting of men's fertility in the United States and Great Britain: A research note. Demography, 36, 135-144.

Santrock, J. W., \& Sitterle, K. A. (1987). Parent-child relationships in stepmother families. In K. Pasley and M. Ihinger-Tallman (Eds.), Remarriage and stepparenting (pp. 273-302). New York: Guilford Press.

Sassler, S., \& Jobe, T. (2002, May). To live together. . . as man and wife? The process of entering into cohabiting unions. Paper presented at the annual meeting of the Population Association of America, Atlanta, GA.

Seltzer, J. A. (1991). Relationship between fathers and children who live apart: The father's role after separation. Journal of Marriage and the Family, 53, 79101.

Seltzer, J. A., \& Brandreth, Y. (1994). What fathers say about involvement with children after separation. Journal of Family Issues, 15, 49-77.

Smith, D. (1990). Stepmothering. New York: St. Martin's Press.

Smock, P. J. (1990). Remarriage patterns of Black and White women: Reassessing the role of educational attainment. Demography, 27, 467-473.

Smock, P. J. (2000). Cohabitation in the United States: An appraisal of research themes, findings, and implications. Annual Review of Sociology, 26, 1-20.

Smock, P. J., \& Manning, W. D. (1997). Cohabiting partners' economic circumstances and marriage. Demography, 34, 331-341.

Smock, P. J., \& Manning, W. D. (2001, August). A case for qualitative methods in U.S. family demography: Understanding the meaning of unmarried cohabitation. Paper presented at the annual meeting of the American Sociological Association, Annaheim, CA.

Sorensen, E. S. (1997). A national profile of nonresident fathers and their ability to pay child support. Journal of Marriage and the Family, 59, 585-591.

Spanier, G. B., \& Glick, P. C. (1980). Paths to remarriage. Journal of Divorce, 3, 283-298.

Stewart, S. D. (2001). Contemporary American stepparenthood: Integrating cohabiting and nonresident stepparents. Population Research and Policy Review, 20, 345-364.

Sweeney, M. M. (1997a). Remarriage of women and men after divorce. Journal of Family Issues, 18, 479502.

Sweeney, M. M. (1997b, August). The decision to divorce and subsequent remarriage: Does it matter which spouse chose to leave? Presented at the 1996 annual meetings of the American Sociological Association, New York City.

Sweeney, M. M. (1997c). Women, men, and changing families: The shifting economic foundations of marriage. CDE Working Paper No. 97-14, Center for Demography and Ecology. Madison, WI: University of Wisconsin-Madison.

Sweet, J. A., Bumpass, L. L., \& Call, V. (1988). The design and content of the National Survey of Families and Households. National Survey of Families and 
Households Working Paper No. 1. Center for Demography and Ecology. Madison, WI: University of Wisconsin-Madison.

Teachman, J. D. (1991). Who pays? Receipt of child support in the United States. Journal of Marriage and the Family, 53, 759-772.

Teachman, J. D., \& Heckert, A. (1985). The impact of age and children on remarriage. Journal of Family Issues, 6, 185-203.

Thornton, A. (1991). Influence of the marital history of parents on the marital and cohabitational experiences of children. American Journal of Sociology, 96, 868894.

Thornton, A., Axinn, W. G., \& Hill, D. H. (1992). Reciprocal effects of religiosity, cohabitation, and marriage. American Journal of Sociology, 98, 628-651.

Thornton, A., Axinn, W. G., \& Teachman, J. D. (1995). The influence of school enrollment and accumulation on cohabitation and marriage in early adulthood. American Sociological Review, 60, 762-774.

Trivers, R. L. (1974). Parent-offspring conflict. American Zoologist, 11, 249-264.
Veum, J. R. (1993). The relationship between child support and visitation: Evidence from longitudinal data. Social Science Research, 22, 229-244.

Waller, M. R., \& McLanahan, S. (2001). Do unmarried parents' expectations predict marital transitions? Center for Research on Child Well-Being Working Paper No. 01-03-FF. Center for Research on Child Well-being. Princeton, NJ: Princeton University.

Wilson, B. F., \& Clarke, S. C. (1992). Remarriages: A demographic profile. Journal of Family Issues, 13, 123-141.

Wolf, W. C., \& MacDonald, M. M. (1979). The earnings of men and remarriage. Demography, 16, 389-399.

Yun, K. (1992). Effects of child support on remarriage of single mothers. In I. Garfinkle, S. S. McLanahan, \& P. K. Robins (Eds.), Child support assurance (pp. 315-338). Washington, DC: Urban Institute Press.

Zill, N. (1996). Noncustodial parents' participation in their children's lives: Evidence from the Survey of Income and Program Participation. Washington, DC: U.S. Department of Health and Human Services. 